\title{
A Concise Route to Water-Soluble 2,6-Disubstituted BODIPY- Carbohydrate Fluorophores by Direct Ferrier-Type C-Glycosylation
}

\author{
Ana M. Gómez,* Clara Uriel, Ainhoa Oliden-Sánchez, Jorge Bañuelos,* Inmaculada Garcia-Moreno, \\ and J. Cristobal López*
}

Cite This: J. Org. Chem. 2021, 86, 9181-9188

Read Online

\section{ACCESS}

Џlll Metrics \& More

Article Recommendations

Supporting Information

ABSTRACT: Novel, linker-free, BODIPY-carbohydrate derivatives containing sugar residues at positions $\mathrm{C} 2$ and $\mathrm{C} 6$ are efficiently obtained by, hitherto unreported, Ferrier-type $C$-glycosylation of 8aryl-1,3,5,7-tetramethyl BODIPYs with commercially available tri-Oacetyl-D-glucal followed by saponification. This transformation, which involves the electrophilic aromatic substitution $\left(S_{E} A r\right)$ of the dipyrrin framework with an allylic oxocarbenium ion, provides easy access to BODIPY-carbohydrate hybrids with excellent photophysical properties and a weaker tendency to aggregate in concentrated water solutions.

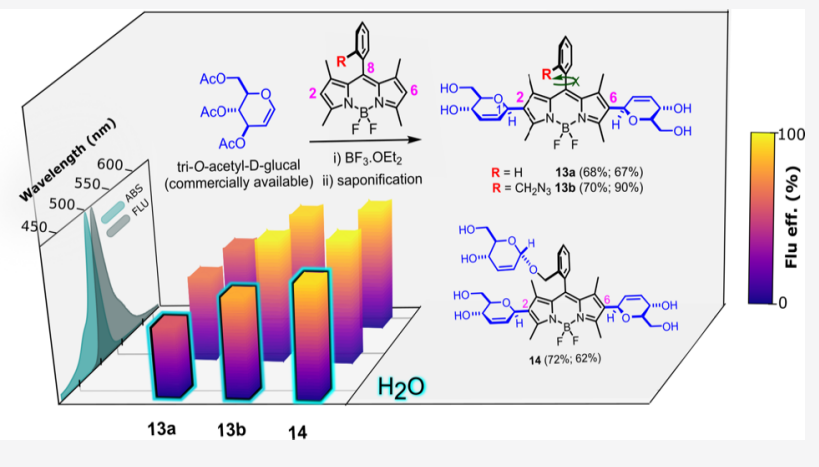

$\mathrm{T}$ he burgeoning interest in fluorescence imaging techniques as non-invasive, highly sensitive, and operationally simple ways to visualize biological processes has spurred the development of biocompatible, water-soluble fluorophores. ${ }^{1}$ In this context, the consideration of boron dipyrromethene difluoride (BODIPY) dyes, e.g., 1 (Figure 1), has amply

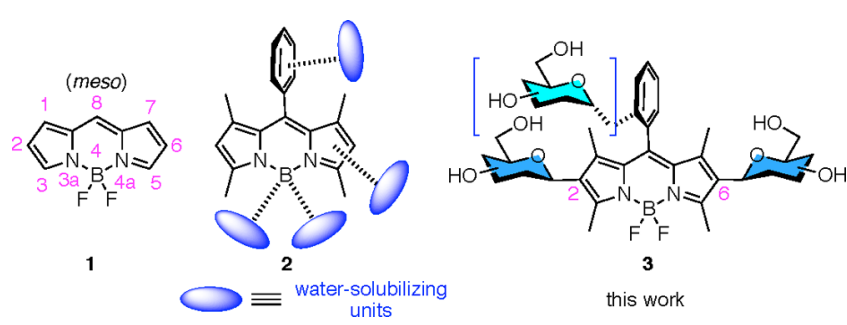

Figure 1. BODIPY (1, IUPAC numbering), BODIPY equipped for solubilization in water (2), and water-soluble, linker-free, 2,6substituted glyco-BODIPYs (3).

surpassed that of the traditionally studied fluorescein, cyanine, and rhodamine fluorophores. ${ }^{2}$ Thus, among other fluorophores, BODIPYs excel in their remarkable properties, including strong absorption, high molar absorption coefficients and fluorescence quantum yields, good chemical and photochemical stability, and low toxicity. ${ }^{3}$ Nevertheless, arguably, their main appeal might be their ability to fine-tune their spectroscopic and photophysical properties by postfunctional modifications of the dipyrromethene core. ${ }^{4}$

In this context, a variety of postfunctionalization studies have emerged to improve water solubility and minimize aggregation-induced quenching of BODIPY fluorophores. ${ }^{5}$
These studies have involved the peripheral incorporation of charged anionic, cationic, and zwitterionic functionalities, the grafting of the BODIPY to neutral hydrophilic compounds, or combinations thereof, e.g., 2 (Figure 1 ).$^{6-8}$ On the contrary, the introduction of bulky substituents into the fluorophore core, or at the apical position, has been used to prevent aggregation, a phenomenon known to lower the quantum yield of fluorophores.

Among the neutral hydrophilic derivatives employed for solubilization of BODIPYs, carbohydrates have received more consideration. This attention is, very likely, motivated by the fact that carbohydrates, in addition to water solubility, might provide biocompatibility and enhanced targeting ability to the ensuing glyco-BODIPYs. ${ }^{10}$

In general, carbohydrates have been incorporated into the periphery of the BODIPY core, frequently by being attached to alkyl or aryl substituents located at the meso (C8) position, ${ }^{11}$ or at the boron atom, ${ }^{12}$ normally through a linker, in transformations that generally involve copper(I)-catalyzed azide-alkyne cycloadditions (CuAAC). ${ }^{13}$ On the contrary, scarce examples of $\mathrm{O}$-glycosylation reactions, the most common being the glycosyl coupling method, ${ }^{14}$ have been reported for the assembly of carbohydrates with BODIPYs. ${ }^{15}$

Received: February 19, 2021

Published: June 22, 2021 
According to these precedents, we envisioned that it would be of interest to develop a $C$-glycosylation protocol $^{16}$ that could engage positions $\mathrm{C} 2$ and $\mathrm{C} 6$ of the BODIPY core, in commonly used 1,3,5,7-tetramethyl BODIPYs. Such a method could provide direct access to "linker-free", nonhydrolyzable, water-soluble bis-C-glycosidic BODIPYs, e.g., 3 (Figure 1).

Thus, even though positions $\mathrm{C} 2$ and $\mathrm{C} 6$ of the boraindacene core are prone to experiencing electrophilic aromatic substitution $\left(\mathrm{S}_{\mathrm{E}} \mathrm{Ar}\right)$ reactions, ${ }^{4}$ to the best of our knowledge, no $C$-glycosylation reaction has been reported to date. In this context, we had already observed the reluctance of the BODIPY core to undergo such a reaction in glycosylations of hydroxyl-containing BODIPYs with common glycosyl donors, where no sign of $C$-glycosylation adducts had been detected. ${ }^{15 \mathrm{~b}, \mathrm{~d}}$ Furthermore, in the course of this work, the attempted reaction of 8-aryl-1,3,5,7-tetramethyl BODIPYs with glycosyl trichloroacetimidate donors failed to provide any $C$ glycosylated BODIPYs. We, therefore, reasoned that compared to a classical glycosyl oxonium ion, e.g., 4 (Figure 2), arising

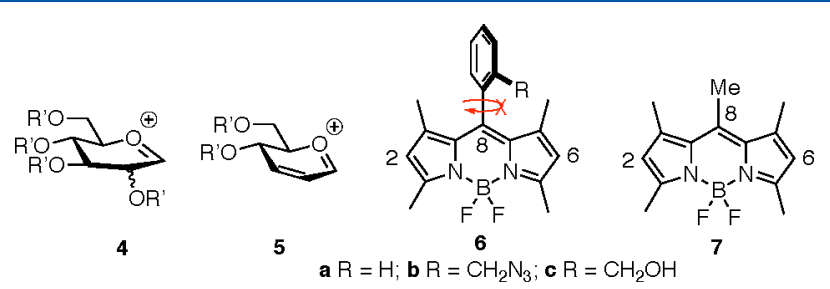

Figure 2. Glycosyl cation (4), allylic glycosyl cation (5), and 8(meso)-substituted 1,3,5,7-tetramethyl BODIPYs $\mathbf{6 a}-\mathbf{c}$ and 7.

from a standard glycosyl donor, a more stabilized and less sterically encumbered, allylic oxocarbenium ion, i.e., $\mathbf{5}$ (Figure 2), ${ }^{17,18}$ might be able to glycosylate the 4-bora-3a,4a-diaza-sindacene skeleton. Under such premises, we decided to test the electrophilic Ferrier-type $C$-glycosylation reaction (which involves allylic cation 5) of 8-aryl and 8-methyl 1,3,5,7tetramethyl BODIPYs 6 and 7, respectively (Figure 2).

Ferrier-type glycosylations involve the treatment of $\Delta^{1,2}$. unsaturated monosaccharides, 1,5-anhydrohex-1-enitols, commonly termed glycals, e.g., 8 (Scheme 1), with a Lewis acid to

Scheme 1. Ferrier-Type Glycosylation of BODIPYs 6a-c with Tri- $O$-acetyl-D-glucal 8

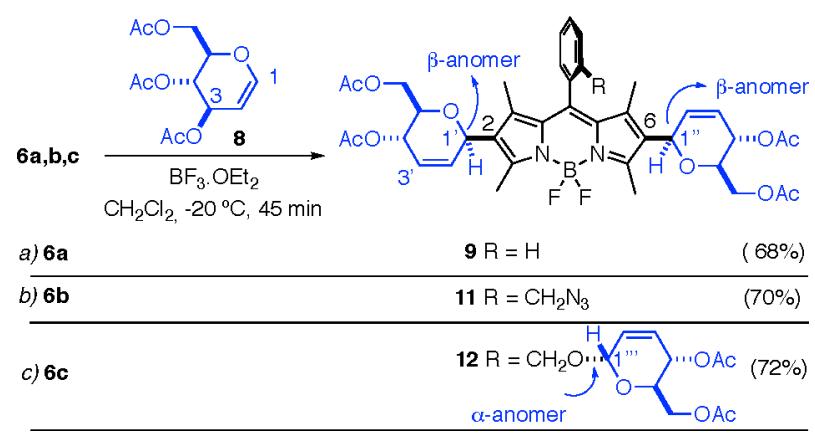

generate reactive electrophilic species $5{ }^{17,18}$ Accordingly, we tested the reaction of meso-phenyl BODIPY 6a with commercially available tri- $O$-acetyl-D-glucal (3,4,6-tri- $O$-acetyl-1,5-anhydro-2-deoxy-D-arabino-hex-1-enitol) 8 in the presence of three different Lewis acids, $\mathrm{BF}_{3} \cdot \mathrm{OEt}_{2}, \mathrm{InCl}_{3}$, and $\mathrm{Yb}(\mathrm{OTf})_{3}$. The best results were observed when 8 (3.0 equiv) and BODIPY 6a were treated with $\mathrm{BF}_{3} \cdot \mathrm{OEt}_{2}(0.15$ equiv) at
$-20{ }^{\circ} \mathrm{C}$ in dichloromethane. Under these conditions, bis- $\beta$ BODIPY-C-glycoside 9 was obtained as the sole isomer in $68 \%$ yield (Scheme 1a). Remarkably, the incorporation of the two glycosyl units at $\mathrm{C} 2$ and $\mathrm{C} 6$ of the BODIPY core in 9 had taken place in a completely regioselective $\left(\mathrm{Cl}^{\prime}\right.$ rather than $\mathrm{C}^{\prime}$ ) and stereoselective manner (vide infra) ${ }^{19,20}$ with regard to the carbohydrate moiety (Scheme 1a). Likewise, glycosylation of 8-o-azidomethyl phenyl BODIPY $\mathbf{6 b}$ with D-glucal 8 (4.0 equiv) provided compound 11, again as a single regio- and stereoisomer, in $70 \%$ yield (Scheme $1 \mathrm{~b}$ ). Next, the reaction of 8-o-hydroxymethyl phenyl BODIPY $6 \mathrm{c}$, containing an additional hydroxyl site for glycosylation, with glycal 8 (5.0 equiv) provided tris-glycosyl BODIPY $\mathbf{1 2}$ as a single $\alpha, \beta, \beta$ stereoisomer (the $O$-glycosylation at the meso o-hydroxymethyl substituent was ascribed as $\alpha$, according to well-established literature precedents on the Ferrier glycosylation of alcohols) ${ }^{17}$ in $72 \%$ yield (Scheme 1c). Conversely, the attempted glycosylation of pentamethyl BODIPY 7, under similar reaction conditions, led only to extensive decomposition of the fluorophore.

The $\beta$ configuration at the anomeric center $\left(\mathrm{Cl}^{\prime}\right.$ or $\left.\mathrm{C}^{\prime \prime}{ }^{\prime \prime}\right)$ on each hex-2-eno-pyranoside moieties in compound 9 was rigorously established by hydrogenation to corresponding saturated derivative 10 (Figure 3), whose ${ }^{1} \mathrm{H}$ NMR analysis

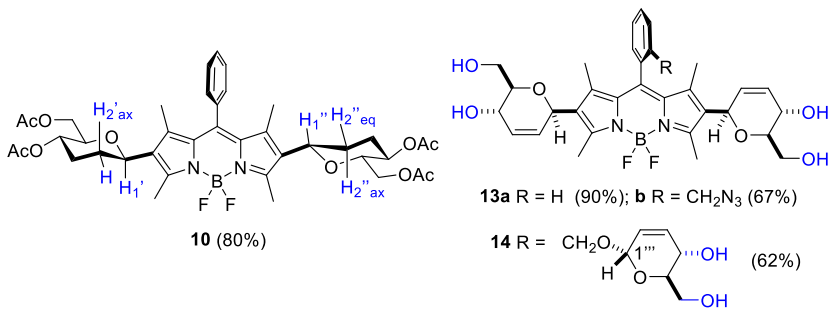

Figure 3. Glyco-BODIPYs 10, 13a, 13b, and 14.

allowed us to assess the axial orientation of the carbohydrate $\mathrm{H} 1^{\prime}$ and $\mathrm{H} 1^{\prime \prime}$ protons. $^{21}$ Saponification of the acyl groups in BODIPY-saccharides 9, 11, and $\mathbf{1 2}$ was performed by treatment with $\mathrm{Et}_{3} \mathrm{~N} / \mathrm{MeOH}(1: 4)$ and led to water-soluble tetraols 13a and $\mathbf{1 3 b}$ and hexaol 14, respectively (Figure 3).

Azidomethyl BODIPY $\mathbf{6 b}$ was selected in this study because the ensuing $C$-glycosyl BODIPYs $\mathbf{1 1}$ and $\mathbf{1 3 b}$ possess an additional site $\left(\mathrm{N}_{3}\right)$ for conjugation. ${ }^{11 \mathrm{~d}, 15 \mathrm{~b}, 22}$ One example of the versatility of these compounds was provided by the onepot dimerization of 11 and $\mathbf{1 3 b}$, leading to bis-urea derivatives 15 and 16, respectively (Figure 4). ${ }^{22}$

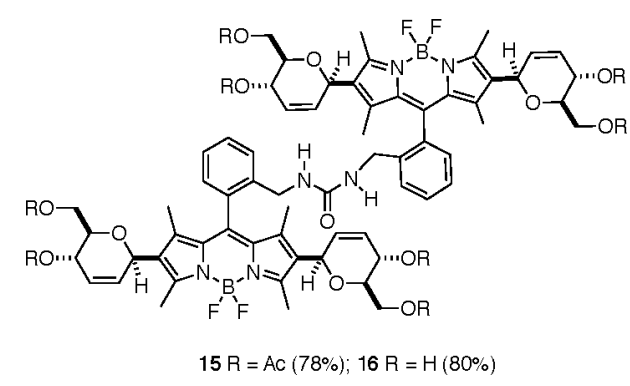

Figure 4. Bis-BODIPY ureas 15 and 16 , obtained by dimerization of $1 \mathbf{1}$ and $\mathbf{1 3 b}$, respectively $\left[\mathrm{Et}_{3} \mathrm{NHCO}_{3}\right.$ (TEAB) (4.0 equiv), $\mathrm{PPh}_{3}(1.5$ equiv)]. 
The photophysical behavior of the new glyco-BODIPYs was evaluated under both soft and laser irradiation. The smallmolecule BODIPY-C-glycosides (acetylated 9, 11, and 12 and saponified 13a, 13b, and 14) displayed strong absorption and fluorescence bands centered around 510 and $520 \mathrm{~nm}$, respectively, showing the low negative solvatochromism distinctive of these fluorophores (Figure S1). ${ }^{15 \mathrm{~b}}$ The conformationally restricted molecular geometry of the new glyco-dyes led to an efficient fluorescence emission with quantum yields ranging from $50 \%$ to $90 \%$ and monoexponential lifetimes ranging from 3 to 5 ns (Figure 5 and Table 1).

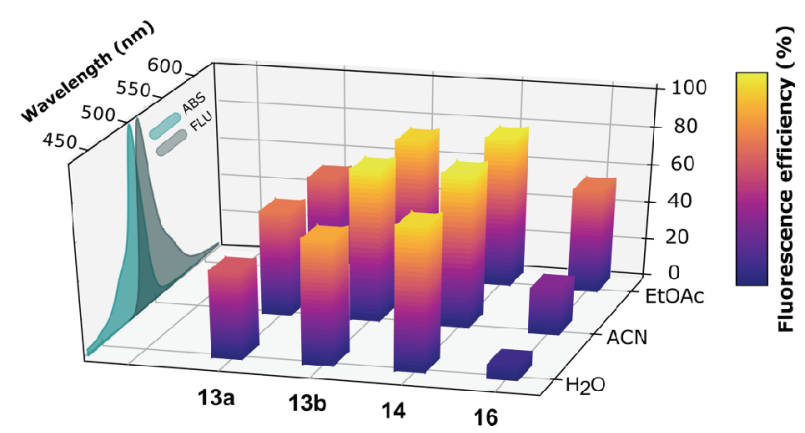

Figure 5. Variation of the fluorescence efficiency with the solvent (EtOAc, $\mathrm{CH}_{3} \mathrm{CN}$, and $\mathrm{H}_{2} \mathrm{O}$ ) for BODIPYs 13a, 13b, and 14 and bisBODIPY 16, all grafted to unprotected sugar units. Representative absorption and fluorescence spectra are also included.

Table 1. Photophysical Properties of Glyco-BODIPYs with Protected $(9,11,12$, and 15, in ethyl acetate) and Unprotected (13a, 13b, 14, and 16, in water) Carbohydrate Moieties (dye concentration of $2 \mu \mathrm{M})^{a}$

$\begin{array}{lcrrrl} & \lambda_{\mathrm{ab}}(\mathrm{nm}) & \varepsilon_{\max }(f)\left(\times 10^{4} \mathrm{M}^{-1} \mathrm{~cm}^{-1}\right) & \lambda_{\mathrm{fl}}(\mathrm{nm}) & \phi & \tau(\mathrm{ns}) \\ 9 & 509.0 & 10.4(0.57) & 521.0 & 0.66 & 3.68 \\ 11 & 512.5 & 8.8(0.48) & 525.0 & 0.91 & 4.93 \\ 12 & 511.5 & 10.9(0.58) & 522.5 & 0.88 & 5.06 \\ 15 & 510.0 & 14.9(0.71) & 523.5 & 0.59 & 4.72^{b} \\ 13 \mathrm{a} & 504.5 & 3.5(0.30) & 517.0 & 0.47 & 3.42 \\ 13 \mathrm{~b} & 509.0 & 5.6(0.40) & 521.5 & 0.67 & 5.14 \\ 14 & 508.0 & 5.9(0.40) & 521.0 & 0.77 & 5.26 \\ 16 & 507.5 & 8.0(0.50) & 522.0 & 0.08 & 3.81^{b}\end{array}$

${ }^{a}$ Full photophysical data for the saponified compounds are listed in Table S1 for the single BODIPYs and Table S3 for the bis-BODIPYs. Absorption $\left(\lambda_{\mathrm{ab}}\right)$ and fluorescence $\left(\lambda_{\mathrm{fl}}\right)$ wavelengths, molar absorption coefficients at the maximum $\left(\varepsilon_{\max }\right)$, oscillator strengths $(f)$, fluorescence quantum yields $(\phi)$, and lifetimes $(\tau)$ are given. Estimate errors: $\pm 0.5 \mathrm{~nm}$ for wavelengths and $5 \%$ for the rest of the parameters. ${ }^{b}$ Amplitude average lifetime of the resulting biexponential fit of the decay curves (Table S3).

The theoretical simulation of the optimized molecular geometries of the glyco-BODIPYs confirmed that the persubstitution of the dipyrrin system exerted the desired sterical hindrance at the 2,6-saccharides and, especially, at the 8 -aryl moiety, placing all of these rings orthogonal to the chromophoric core (Figure S2). In this way, nonradiative deactivation funnels related to the free motion of the substituents were at least partially hindered, because further structural constraints still ameliorated the fluorescence response (Table 1). In fact, the 8-aryl moiety in 9 and 13a, despite the 1,7-methylation of the dipyrrin, could retain some rotational freedom around its perpendicular disposition, decreasing the fluorescence efficiency to $50 \%$. Further sterical hindrance asserted by ortho substitution at this 8 -aryl moiety completely locked its slight rotational motion, fixing its structural disposition. ${ }^{23}$ This structural arrangement entailed a more efficient fluorescence response $(\leq 90 \%)$ owing to a decrease in the nonradiative rate constant (Figure 5 and Table S1). Although overall the photophysical signatures of the acetylated and hydroxyl-free glyco-BODIPYs are quite similar (Table 1 and Table S1), decreases in both the absorption and the fluorescence probability are found upon deprotection of the carbohydrate moieties. The absorption spectral profile of the unprotected glyco-BODIPYs becomes slightly flattened and broadened [full width at half-maximum (fwhm) increase around $\left.100 \mathrm{~cm}^{-1}\right]$, leading to a decrease in the molar absorption coefficient that runs simulatenously with a less pronounced decrease in the corresponding oscillator strength [calculated from the area under the absorption band (see Table 1 and Table S1)].

BODIPYs grafted to unprotected sugar units (13a, 13b, and 14) were completely soluble in water in the millimolar range at room temperature (Figure S3) and retained a noticeable fluorescence efficiency [i.e., $\leq 77 \%$ for $\mathbf{1 4}$ (Figure 5 and Table $1)$. Increasing the dye concentration in water altered neither the absorption nor the fluorescence profiles, highlighting the absence of intermolecular aggregation, the most effective deactivation pathway of BODIPY in water, which is unambiguously tracked through the drastic changes induced in the spectral bands. ${ }^{9 c}$ Therefore, these glyco-BODIPYs are not prone to aggregate even after reaching their solubility limit in water (Figure S3). The highly constrained geometrical molecular arrangement of the new glycosylated BODIPYs entailed an enhanced water solubility while hindering any intermolecular exciton coupling of these inherently hydrophobic chromophores. Thus, it appears that the conformational rigidity asserted by the direct linkage of the bulky saccharides at positions C2 and C6 and the orthogonal disposition of the 8-aryl moiety with respect to the main plane of the chromophoric framework hampered the stacking of the boradiazaindacene units in concentrated water solutions. This phenomenon was even reinforced when a third hydrophilic, bulky, sugar unit was incorporated at one of the apical positions of the BODIPY chromophore, as in 14, thus shielding one of the faces perpendicular to the BODIPY core. $^{9 \mathrm{~b}}$ Therefore, $C$-glycosylation of the BODIPY skeleton might then be visualized as a concise and suitable strategy for fine-tuning its water solubility while keeping a notable fluorescence response even in high-optical density media.

Understanding laser-induced photophysical behavior is key in the engineering of photonic materials for advanced applications such as high-resolution microscopy techniques involving laser radiation as an excitation source. Therefore, the lasing properties of the new glycosylated derivatives were studied, according to their absorption properties, under pumping radiation at both 355 and $532 \mathrm{~nm}$. Laser emission, centered in the 556-568 nm spectral region, was recorded from the new dyes with efficiencies of $\leq 22 \%$ (see Table S2). A further important parameter is the dye photostability over long operation times. Long-lasting efficient emitters under lasing irradiation are sought to reach the nominal resolution of the most advanced optical microscopy. The photostability of the new dyes was analyzed by the decay of its laser-induced fluorescence (LIF) intensity in an ethyl acetate solution upon severe laser pumping (see the Supporting Information for 
experimental details). All of the glyco-BODIPYs studied (acylated and saponified derivatives) displayed a high photostability because their LIF emission decreased by merely $10 \%$ of its initial value after 70000 pump pulses at a repetition rate of $10 \mathrm{~Hz}$.

The spectral bands of the urea-bridged bis-BODIPYs featuring $\mathrm{C} 2, \mathrm{C} 6$ carbohydrate units (15 and 16) showed profiles similar to those described above for the small-molecule saccharidic BODIPYs, but with higher molar absorption coefficients, owing to the additive contribution of both chromophoric subunits in the dimer (Figure S4). Unprotected bis-BODIPY 16 showed a limited water solubility, being fully dissolved just in the micromolar range. The appended carbohydrates were likely not able to efficiently decrease the hydrophobic nature of the dimeric urea. The fluorescence response of $\mathbf{1 6}$ is lower than that of its corresponding monomeric precursor, especially in polar media (Figure 5 and Table S3). Similar results were previously reported for nonglycosylated urea-bridged bis-BODIPYs. ${ }^{22,24}$ As mentioned above, each chromophoric fragment retains its molecular identity after covalent assembly, thus showing isoenergetic excited states and electronic transitions that enable energy and electron transfer processes. The migration of energy between bridged BODIPY units could quench the fluorescence through the dissipation of excitation energy as heat, but it solely cannot explain the marked solvent-sensitive fluorescence response of 16. Such polarity-triggered fluorescence quenching was ascribed to an additional nonradiative pathway such as photoinduced electron transfer (PET) between the pair of identical BODIPYs electronically decoupled in the ground state. $^{22-25}$ This electron transfer mechanism with no electrostatic driving force is enhanced by the solvent polarity, thus decreasing the fluorescence efficiency in polar media (Figure 5 and Table S3).

Even though this PET process was detrimental to the fluorescence response, it paved the way to new photoinduced pathways. In fact, the ability of electron transfer to mediate in the triplet state population is actively applied to develop heavy atom-free singlet oxygen photosensitizers for photodynamic therapy (PDT). ${ }^{26}$ Against this background, and bearing in mind the aforementioned ongoing PET in the glycosylated bisBODIPY, $^{22}$ we analyzed its suitability to generate singlet oxygen in chloroform. Bis-BODIPY 16 yielded a singlet oxygen generation efficiency of $12 \%$, while retaining a fluorescence response of $58 \%$ in this solvent (Table S3). Therefore, this bisglyco-BODIPY could be envisaged as an effective theranostic agent allowing simultaneously imaging (fluorescence) and phototreatment (singlet oxygen generation). Note that the rest of the herein reported monomeric glycoprobes (13 and 14) did not display such emission, supporting the key role on the PET in mediating the population of the triplet manifold and overall in the fluorescence signatures of bis-BODIPYs.

In summary, we have reported a concise method for the incorporation of at least two sugar units at $\mathrm{C} 2$ and $\mathrm{C} 6$ into the BODIPY core in 8-aryl 1,3,5,7-tetramethyl BODIPYs by direct Ferrier-type $C$-glycosylation of the boradiaza-s-indacene core. The presence of an aryl group at C8 appeared to be necessary for the reaction to succeed, probably by stabilizing positively charged reactive species because a related meso-methyl BODIPY underwent extensive decomposition. The constrained geometry of these C-glycosyl BODIPYs avoids aggregation in highly concentrated aqueous media, thus showing improved water solubility while retaining a bright and stable emission. In addition, the ongoing PET in watersoluble glycosylated bis-BODIPYs enables singlet oxygen generation while retaining a fluorescence response being suited for theranostic purposes.

\section{EXPERIMENTAL SECTION}

General Information. All solvents and reagents were obtained commercially and used as received unless stated otherwise. Residual water was removed from starting compounds by repeated coevaporation with toluene. All moisture-sensitive reactions were performed in dry flasks fitted with glass stoppers or rubber septa under a positive pressure of argon. Anhydrous $\mathrm{MgSO}_{4}$ or $\mathrm{Na}_{2} \mathrm{SO}_{4}$ was used to dry organic solutions during workup. Evaporation of the solvents was performed under reduced pressure using a rotary evaporator. Flash column chromatography was performed using 230400 mesh silica gel. Thin-layer chromatography was conducted on Kieselgel 60 F254. Spots were observed first under UV irradiation $(254 \mathrm{~nm})$ and then by charring with a solution of $20 \%$ aqueous $\mathrm{H}_{2} \mathrm{SO}_{4}(200 \mathrm{~mL})$ in $\mathrm{AcOH}(800 \mathrm{~mL})$. All melting points were determined with a Stuart SMP-20 apparatus. Optical rotations were measured on a Jasco P2000 polarimeter with $[\alpha]_{\mathrm{D}}{ }^{25}$ values reported in degrees with concentrations expressed in grams per $100 \mathrm{~mL} .{ }^{1} \mathrm{H}$ and ${ }^{13} \mathrm{C}$ NMR spectra were recorded in $\mathrm{CDCl}_{3}$ or $\mathrm{CD}_{3} \mathrm{OD}$ at 300,400 , or $500 \mathrm{MHz}$ and 75, 101, or $126 \mathrm{MHz}$, respectively. Chemical shifts are expressed in parts per million $(\delta)$ downfield from tetramethylsilane and are referenced to residual protium in the NMR solvent $\left(\mathrm{CHCl}_{3}, \delta\right.$ 7.25; $\left.\mathrm{CH}_{3} \mathrm{OH}, \delta 4.87\right)$. Coupling constants $(J)$ are given in hertz. All presented ${ }^{13} \mathrm{C}$ NMR spectra are proton-decoupled. Mass spectra were recorded by direct injection with an Accurate Mass Q-TOF LC/MS spectrometer equipped with an electrospray ion source in positive mode.

General Method for the $\mathrm{BF}_{3} \cdot \mathrm{OEt}_{2}$-Catalyzed Ferrier Reaction of BODIPYs with Acetylated Glucal 8. To a stirred solution of tri-O-acetyl-D-glucal 8 (3-5 equiv) and the appropriate BODIPY (1 equiv) in anhydrous $\mathrm{CH}_{2} \mathrm{Cl}_{2}(20 \mathrm{~mL} / \mathrm{mmol})$ was added $4 \AA$ molecular sieves. The mixture was stirred at room temperature (rt) for $\sim 15$ min under an $\mathrm{Ar}$ atmosphere and then cooled to $-20{ }^{\circ} \mathrm{C}$. $\mathrm{BF}_{3} \cdot \mathrm{OEt}_{2}(0.15$ equiv) was then added. The mixture was stirred under these conditions for $45-90 \mathrm{~min}$, poured into $5 \mathrm{~mL}$ of a saturated aqueous $\mathrm{NaHCO}_{3}$ solution, and partitioned twice with $10 \mathrm{~mL}$ of $\mathrm{CH}_{2} \mathrm{Cl}_{2}$. The combined organic layers were washed once with brine, dried over $\mathrm{MgSO}_{4}$, and filtered, and the solvent was removed in vacuo. The crude material was purified through silica gel column chromatography.

2,6-Bis(4,6-di-O-acetyl-2,3-dideoxy- $\beta$-D-erythro-hex-2-enopyranosyl)-8-phenyl-1,3,5,7-tetramethyl-4,4-difluoro-4-bora-3a,4adiaza-s-indacene (9). BODIPY 6a $(80 \mathrm{mg}, 0.25 \mathrm{mmol})$ was reacted with tri- $O$-acetyl-D-glucal $8(204 \mathrm{mg}, 0.75 \mathrm{mmol})$ and $\mathrm{BF}_{3} \cdot \mathrm{OEt}_{2}(4.6$ $\mu \mathrm{L}, 0.04 \mathrm{mmol})$ following the general procedure $\left(-20{ }^{\circ} \mathrm{C}, 45 \mathrm{~min}\right)$. The residue was purified by flash silica gel chromatography (9:1 hexane/ethyl acetate) to give derivative $9(127 \mathrm{mg}, 68 \%)$ : red solid; $\mathrm{mp} 82-83{ }^{\circ} \mathrm{C} ;[\alpha]_{\mathrm{D}}^{21}=+98.1\left(c 0.025, \mathrm{CHCl}_{3}\right) ;{ }^{1} \mathrm{H}$ NMR $(300$ $\left.\mathrm{MHz}^{\mathrm{CDCl}}\right)_{3} \delta 7.49-7.46(\mathrm{~m}, 3 \mathrm{H}), 7.23-7.20(\mathrm{~m}, 2 \mathrm{H}), 5.83-5.73$ $(\mathrm{m}, 4 \mathrm{H}), 5.36-5.32(\mathrm{~m}, 2 \mathrm{H}), 5.20-5.18(\mathrm{~m}, 2 \mathrm{H}), 4.22(\mathrm{dd}, J=12.1$, $2.5 \mathrm{~Hz}, 2 \mathrm{H}), 4.13(\mathrm{dd}, J=12.1,5.3 \mathrm{~Hz}, 2 \mathrm{H}), 3.85$ (ddd, $J=9.1,5.3$, $2.5 \mathrm{~Hz}, 2 \mathrm{H}), 2.57(\mathrm{~s}, 6 \mathrm{H}), 2.08(\mathrm{~s}, 6 \mathrm{H}), 2.04(\mathrm{~s}, 6 \mathrm{H}), 1.34(\mathrm{~s}, 6 \mathrm{H})$; ${ }^{13} \mathrm{C}\left\{{ }^{1} \mathrm{H}\right\}$ NMR $\left(75 \mathrm{MHz}, \mathrm{CDCl}_{3}\right) \delta 171.0,170.4,155.3,142.6,141.3$, 135.1, 133.8, 131.6, 131.0, 129.4, 129.3, 129.0, 128.6, 128.0, 127.8, 125.2, 75.0, 69.9, 65.1, 63.5, 21.1, 20.8, 13. 4, 12.2; HRMS (ESI) $\mathrm{m} / \mathrm{z}$ calcd for $[\mathrm{M}+\mathrm{H}]^{+} \mathrm{C}_{39} \mathrm{H}_{44} \mathrm{BF}_{2} \mathrm{~N}_{2} \mathrm{O}_{10} 749.3058$, found 749.3051; HRMS (ESI) $m / z$ calcd for $\left[\mathrm{M}+\mathrm{NH}_{4}\right]^{+} \mathrm{C}_{39} \mathrm{H}_{47} \mathrm{BF}_{2} \mathrm{~N}_{3} \mathrm{O}_{10} 766.3313$, found 766.3324 .

2,6-Bis(4,6-di-O-acetyl-2,3-dideoxy- $\beta$-D-erythro-hex-2-enopyranosyl)-8-(2-azidomethyl)-phenyl-1,3,5,7-tetramethyl-4,4-difluoro4-bora-3a,4a-diaza-s-indacene (11). BODIPY $6 \mathbf{b}(130 \mathrm{mg}, 0.34$ $\mathrm{mmol})$ was reacted with tri- $O$-acetyl-D-glucal $8(280 \mathrm{mg}, 1.03 \mathrm{mmol})$ and $\mathrm{BF}_{3} \cdot \mathrm{OEt}_{2}(6 \mu \mathrm{L}, 0.05 \mathrm{mmol})$ following the general procedure $\left(-20{ }^{\circ} \mathrm{C}, 45 \mathrm{~min}\right)$. The residue was purified by flash silica gel chromatography (9:1 toluene/ethyl acetate) to give derivative 11 
(191 mg, 70\%): red solid; mp 68-69 ${ }^{\circ} \mathrm{C} ;[\alpha]_{\mathrm{D}}^{21}=-60.5(c 0.025$, $\mathrm{CHCl}_{3}$ ); ${ }^{1} \mathrm{H}$ NMR (500 MHz, $\left.\mathrm{CDCl}_{3}\right) \delta 7.58-7.53(\mathrm{~m}, 2 \mathrm{H}), 7.45$ $(\mathrm{td}, J=7.5,1.7 \mathrm{~Hz}, 1 \mathrm{H}), 7.19(\mathrm{~d}, J=7.5 \mathrm{~Hz}, 1 \mathrm{H}), 5.83-5.75(\mathrm{~m}$, $4 \mathrm{H}), 5.36-5.34(\mathrm{~m}, 2 \mathrm{H}), 5.20-5.19(\mathrm{~m}, 2 \mathrm{H}), 4.32(\mathrm{bs}, 2 \mathrm{H}), 4.24$ (dd, $J=12.2,2.3 \mathrm{~Hz}, 2 \mathrm{H}), 4.16-4.11(\mathrm{~m}, 2 \mathrm{H}), 3.87-3.84(\mathrm{~m}, 2 \mathrm{H})$, $2.58(\mathrm{~s}, 6 \mathrm{H}), 2.09(\mathrm{~s}, 6 \mathrm{H}), 2.06(\mathrm{~s}, 6 \mathrm{H}), 1.323(\mathrm{~s}, 3 \mathrm{H}), 1.317(\mathrm{~s}, 3 \mathrm{H})$; ${ }^{13} \mathrm{C}\left\{{ }^{1} \mathrm{H}\right\}\left(126 \mathrm{MHz}, \mathrm{CDCl}_{3}\right) \delta 171.1,170.4,156.3,156.1,140.9$, 140.7, 139.8, 134.0, 133.7, 131.50, 131.48, 130.2, 129.2, 129.0, 128.7, $125.42,125.37,75.12,75.07,69.98,69.88,65.11,65.08,63.5,52.1$, 21.2, 21.0, 13.6, 13.5, 11.78, 11.75; HRMS (ESI) $\mathrm{m} / z$ calcd for $[\mathrm{M}+$ $\mathrm{H}]^{+} \mathrm{C}_{40} \mathrm{H}_{45} \mathrm{BF}_{2} \mathrm{~N}_{5} \mathrm{O}_{10}$ 804.3229, found 804.3249.

2,6-Bis(4,6-di-O-acetyl-2,3-dideoxy- $\beta$-D-erythro-hex-2-enopyranosyl)-8-[(4,6-di-O-acetyl-2,3-dideoxy- $\alpha$-D-erythro-hex-2-enopyranosyl)-2-methylphenyl]-1,3,5,7-tetramethyl-4,4-difluoro-4-bora3a,4a-diaza-s-indacene (12). BODIPY $6 \mathrm{c}(50 \mathrm{mg}, 0.14 \mathrm{mmol})$ was reacted with tri-O-acetyl-D-glucal $8(193 \mathrm{mg}, 0.71 \mathrm{mmol})$ and $\mathrm{BF}_{3}$. $\mathrm{OEt}_{2}(3 \mu \mathrm{L}, 0.02 \mathrm{mmol})$ following the general procedure $\left(-20{ }^{\circ} \mathrm{C}, 90\right.$ $\mathrm{min})$. The residue was purified by flash silica gel chromatography $(7: 3$ toluene/ethyl acetate) to give derivative $\mathbf{1 2}(101 \mathrm{mg}, 72 \%)$ : red solid; $\mathrm{mp} \mathrm{88}-89^{\circ} \mathrm{C}$; $[\alpha]_{\mathrm{D}}{ }^{21}=+96.8\left(c 0.02, \mathrm{CHCl}_{3}\right) ;{ }^{1} \mathrm{H}$ NMR $(400 \mathrm{MHz}$, $\left.\mathrm{CDCl}_{3}\right) \delta 7.56(\mathrm{dd}, J=7.2,1.5 \mathrm{~Hz}, 1 \mathrm{H}), 7.50(\mathrm{dt}, J=7.5,1.0 \mathrm{~Hz}$, $1 \mathrm{H}), 7.44(\mathrm{dt}, J=7.5,1.0 \mathrm{~Hz}, 1 \mathrm{H}), 7.17(\mathrm{dd}, J=7.2,1.0 \mathrm{~Hz}, 1 \mathrm{H})$, $5.83-5.59(\mathrm{~m}, 5 \mathrm{H}), 5.34-4.97(\mathrm{~m}, 7 \mathrm{H}), 4.69(\mathrm{~d}, J=11.6 \mathrm{~Hz}, 1 \mathrm{H})$, $4.36(\mathrm{~d}, J=11.6 \mathrm{~Hz}, 1 \mathrm{H}), 4.25-3.83(\mathrm{~m}, 9 \mathrm{H}), 2.58(\mathrm{~s}, 6 \mathrm{H}), 2.09(\mathrm{~s}$, $3 \mathrm{H}), 2.085(\mathrm{~s}, 3 \mathrm{H}), 2.078(\mathrm{~s}, 3 \mathrm{H}), 2.054(\mathrm{~s}, 3 \mathrm{H}), 2.050(\mathrm{~s}, 3 \mathrm{H}), 2.01$ $(\mathrm{s}, 3 \mathrm{H}), 1.33(\mathrm{~s}, 3 \mathrm{H}), 1.32(\mathrm{~s}, 3 \mathrm{H}) ;{ }^{13} \mathrm{C}\left\{{ }^{1} \mathrm{H}\right\}\left(101 \mathrm{MHz}, \mathrm{CDCl}_{3}\right) \delta$ $171.1,170.8,170.5,170.3,156.0,155.5,141.2,140.6,135.3,134.3$, $131.6,130.7,130.5,129.9,129.8,129.7,129.2,128.7,128.5,128.4$, 128.0, 127.9, 127.3, 125.4, 125.3, 94.7, 75.0, 70.0, 69.8, 68.5, 67.2, 65.1, 63.5, 62.6, 21.2, 21.14, 21.10, 20.95, 20.89, 20.85, 13.7, 13.4, 11.9, 11.7; HRMS (ESI) $m / z$ calcd for $\left[\mathrm{M}+\mathrm{NH}_{4}\right]^{+} \mathrm{C}_{50} \mathrm{H}_{61} \mathrm{BF}_{2} \mathrm{~N}_{3} \mathrm{O}_{16}$ 1008.4116, found 1008.4130.

Hydrogenation Reaction of 9. 2,6-Bis(4,6-di-O-acetyl-2,3dideoxy- $\beta$-D-erythro-hex-2-pyranosyl)-8-phenyl-1,3,5,7-tetramethyl4,4-difluoro-4-bora-3a,4a-diaza-s-indacene (10). A solution of compound $9(40 \mathrm{mg}, 0.05 \mathrm{mmol})$ in a $\mathrm{MeOH} / \mathrm{CH}_{2} \mathrm{Cl}_{2}$ mixture [3 $\mathrm{mL}, 1: 1$ $(\mathrm{v} / \mathrm{v})]$ was hydrogenated in a Parr hydrogenator with $10 \% \mathrm{Pd}: \mathrm{C}[10 \%$ $(\mathrm{w} / \mathrm{w})]$ at $25 \mathrm{psi}$. After reaction for $16 \mathrm{~h}$, the catalyst was filtered off, the filtrate evaporated under reduced pressure, and the residue purified by flash chromatography (9:1 hexane/ethyl acetate) to give 10 (31 mg, 80\%): red oil; $[\alpha]_{\mathrm{D}}{ }^{21}=+212.3\left(c 0.13, \mathrm{CHCl}_{3}\right)$; ${ }^{1} \mathrm{H}$ NMR $\left(300 \mathrm{MHz}, \mathrm{CDCl}_{3}\right) \delta 7.49-7.47(\mathrm{~m}, 2 \mathrm{H}), 7.26-7.23(\mathrm{~m}, 3 \mathrm{H}), 4.75$ $(\mathrm{dt}, J=10.0,4.7 \mathrm{~Hz}, 2 \mathrm{H}), 4.39\left(\mathrm{dd}, J_{1,2}=11.6,2.5 \mathrm{~Hz}, 2 \mathrm{H}\right), 4.18-$ $4.16(\mathrm{~m}, 4 \mathrm{H}), 3.59(\mathrm{dt}, J=10.0,3.4 \mathrm{~Hz}, 2 \mathrm{H}), 2.63(\mathrm{~s}, 6 \mathrm{H}), 2.31-2.24$ $(\mathrm{m}, 2 \mathrm{H}), 2.05(\mathrm{~s}, 6 \mathrm{H}), 2.04(\mathrm{~s}, 6 \mathrm{H}), 2.00-1.82(\mathrm{~m}, 2 \mathrm{H}), 1.74-1.49$ $(\mathrm{m}, 4 \mathrm{H}) 1.35(\mathrm{~s}, 6 \mathrm{H}) ;{ }^{13} \mathrm{C} \mathrm{NMR}\left(101 \mathrm{MHz}, \mathrm{CDCl}_{3}\right) \delta 171.4,170.6$, $154.6,142.4,139.9,135.6,131.4,130.2$, 129.7, 129.5, 128.5, 78.2, 73.8, 68.1, 63.6, 30.9, 30.0, 21.6, 21.3, 14.0, 12.6; HRMS (ESI) $\mathrm{m} / z$ calcd for $[\mathrm{M}+\mathrm{H}]^{+} \mathrm{C}_{39} \mathrm{H}_{48} \mathrm{BF}_{2} \mathrm{~N}_{2} \mathrm{O}_{10} 753.3371$, found 753.3365 .

General Method for the Methanolysis of Acetate Esters. A solution of the corresponding acetate $(0.1 \mathrm{mmol})$ in $\mathrm{MeOH}(2 \mathrm{~mL})$ was treated with $\mathrm{Et}_{3} \mathrm{~N}(0.5 \mathrm{~mL})$. The mixture was warmed at $60{ }^{\circ} \mathrm{C}$ (heat-on blocks) and stirred at that temperature overnight. The solution was concentrated in vacuo, and the residue was then purified by flash column chromatography (eluent, dichloromethane/methanol mixtures).

2,6-Bis(2,3-dideoxy- $\beta$-D-erythro-hex-2-enopyranosyl)-8-phenyl1,3,5,7-tetramethyl-4,4-difluoro-4-bora-3a,4a-diaza-s-indacene (13a). BODIPY $9(45 \mathrm{mg}, 0.06 \mathrm{mmol})$ was deacylated according to the general procedure $\left(60{ }^{\circ} \mathrm{C}\right.$, heat-on block, overnight $)$. The residue was purified by flash silica gel chromatography (95:5 dichloromethane/methanol) to give derivative $13 \mathrm{a}(31 \mathrm{mg}, 90 \%)$ : red solid; mp $160-161{ }^{\circ} \mathrm{C} ;[\alpha]_{\mathrm{D}}{ }^{21}=+473.1\left(\right.$ c $\left.0.03, \mathrm{CH}_{3} \mathrm{OH}\right) ;{ }^{1} \mathrm{H}$ NMR $(500$ $\left.\mathrm{MHz}, \mathrm{CD}_{3} \mathrm{OD}\right) \delta 7.58-7.55(\mathrm{~m}, 3 \mathrm{H}), 7.33-7.30(\mathrm{~m}, 2 \mathrm{H}), 5.85(\mathrm{dt}, J$ $=10.5,2.0 \mathrm{~Hz}, 2 \mathrm{H}), 5.68(\mathrm{dt}, J=10.5,2 \mathrm{~Hz}, 2 \mathrm{H}), 5.21-5.20(\mathrm{~m}$, $2 \mathrm{H}), 4.09-4.06(\mathrm{~m}, 2 \mathrm{H}), 3.87$ (dd, $J=12.0,2.0 \mathrm{~Hz}, 2 \mathrm{H}), 3.65$ (dd, $J$ $=12.0,6.5 \mathrm{~Hz}, 2 \mathrm{H}), 3.46(\mathrm{ddd}, J=12.0,6.5,2.5 \mathrm{~Hz}, 2 \mathrm{H}), 2.53(\mathrm{~s}$, $6 \mathrm{H}), 1.39(\mathrm{~s}, 6 \mathrm{H}) ;{ }^{13} \mathrm{C}\left\{{ }^{1} \mathrm{H}\right\}\left(126 \mathrm{MHz}, \mathrm{CD}_{3} \mathrm{OD}\right) \delta 155.2,142.5$, $140.7,135.0,130.5,129.40,129.37,129.1,128.98,128.96,127.95$,
80.8, 69.3, 62.7, 61.9, 12.2, 10.9; HRMS (ESI) $\mathrm{m} / z$ calcd for $[\mathrm{M}+$ $\mathrm{H}]^{+} \mathrm{C}_{31} \mathrm{H}_{36} \mathrm{BF}_{2} \mathrm{~N}_{2} \mathrm{O}_{6}$ 581.2634, found 581.2621.

2,6-Bis(2,3-dideoxy- $\beta$-D-erythro-hex-2-enopyranosyl)-8-(2-azidomethyl)-phenyl-1,3,5,7-tetramethyl-4,4-difluoro-4-bora-3a,4adiaza-s-indacene (13b). BODIPY 11 (59 $\mathrm{mg}, 0.07 \mathrm{mmol}$ ) was deacylated according to the general procedure $\left(60^{\circ} \mathrm{C}\right.$, heat-on block, overnight). The residue was purified by flash silica gel chromatography (95:5 dichloromethane/methanol) to give derivative 13b (31 $\mathrm{mg}, 67 \%): \mathrm{mp} 135-136{ }^{\circ} \mathrm{C} ;[\alpha]_{\mathrm{D}}{ }^{21}=+1090.2\left(c 0.025, \mathrm{CH}_{3} \mathrm{OH}\right) ;{ }^{1} \mathrm{H}$ NMR (400 MHz, $\left.\mathrm{CD}_{3} \mathrm{OD}\right) \delta 7.60-7.50(\mathrm{~m}, 3 \mathrm{H}), 7.24-7.27(\mathrm{~m}$, $1 \mathrm{H}), 5.82(\mathrm{~d}, J=10.2 \mathrm{~Hz}, 2 \mathrm{H}), 5.66(\mathrm{dt}, J=10.2,2.0 \mathrm{~Hz}, 2 \mathrm{H}), 5.17$ (bs, $2 \mathrm{H}), 4.28-4.30(\mathrm{~m}, 2 \mathrm{H}), 4.06-4.02(\mathrm{~m}, 2 \mathrm{H}), 3.86-3.82(\mathrm{~m}$, $2 \mathrm{H}), 3.65-3.60(\mathrm{~m}, 2 \mathrm{H}), 3.45-3.42(\mathrm{~m}, 2 \mathrm{H}), 2.53(\mathrm{~s}, 6 \mathrm{H}), 1.36(\mathrm{~s}$, $6 \mathrm{H}) ;{ }^{13} \mathrm{C}\left\{{ }^{1} \mathrm{H}\right\}\left(101 \mathrm{MHz}, \mathrm{CD}_{3} \mathrm{OD}\right) \delta 155.9,155.8,140.64,140.59$, $139.8,134.2,134.1,130.2,129.8,129.60,129.56,129.37,129.33$, $129.28,129.2,128.8,80.93,80.90,69.35,69.33,62.81,62.78,61.9$, $51.8,12.4,10.7,10.6$; HRMS (ESI) $m / z$ calcd for $[\mathrm{M}+\mathrm{H}]^{+}$ $\mathrm{C}_{32} \mathrm{H}_{37} \mathrm{BF}_{2} \mathrm{~N}_{5} \mathrm{O}_{6}$ 636.2805, found 636.2776; HRMS (ESI) $\mathrm{m} / \mathrm{z}$ calcd for $\left[\mathrm{M}+\mathrm{NH}_{4}\right]^{+} \mathrm{C}_{32} \mathrm{H}_{40} \mathrm{BF}_{2} \mathrm{~N}_{6} \mathrm{O}_{6}$ 653.3070, found 653.3042.

2,6-Bis(2,3-dideoxy- $\beta$-D-erythro-hex-2-enopyranosyl)-8-[(2,3-dideoxy- $\alpha$-D-erythro-hex-2-enopyranosyl)-2-methyl-phenyl]-1,3,5,7tetramethyl-4,4-difluoro-4-bora-3a,4a-diaza-s-indacene (14). BODIPY 12 (42 mg, $0.04 \mathrm{mmol}$ ) was deacylated according to the general procedure $\left(60{ }^{\circ} \mathrm{C}\right.$, heat-on block, overnight). The residue was purified by flash silica gel chromatography (9:1 dichloromethane) methanol) to give derivative $14(18 \mathrm{mg}, 62 \%)$ : red solid; $\mathrm{mp} 148-$ $150{ }^{\circ} \mathrm{C} ;[\alpha]_{\mathrm{D}}{ }^{21}=+354.6\left(c 0.04, \mathrm{CH}_{3} \mathrm{OH}\right) ;{ }^{1} \mathrm{H}$ NMR $(400 \mathrm{MHz}$, $\left.\mathrm{CD}_{3} \mathrm{OD}\right) \delta 7.63(\mathrm{~d}, J=7.5 \mathrm{~Hz}, 1 \mathrm{H}), 7.55-7.46(\mathrm{~m}, 2 \mathrm{H}), 7.20(\mathrm{~d}, J=$ $7.5 \mathrm{~Hz}, 1 \mathrm{H}), 5.92-5.62(\mathrm{~m}, 4 \mathrm{H}), 5.53(\mathrm{~d}, J=10.3 \mathrm{~Hz}, 1 \mathrm{H}), 5.17(\mathrm{~s}$ $2 \mathrm{H}), 4.72-4.60(\mathrm{~m}, 4 \mathrm{H}), 4.29(\mathrm{~d}, J=11.2 \mathrm{~Hz}, 1 \mathrm{H}), 4.06-4.01(\mathrm{~m}$, $3 \mathrm{H}), 3.84(\mathrm{~d}, J=11.5 \mathrm{~Hz}, 2 \mathrm{H}), 3.66-3.56(\mathrm{~m}, 6 \mathrm{H}), 2.52(\mathrm{~s}, 6 \mathrm{H})$, $1.35(\mathrm{~s}, 3 \mathrm{H}), 1.33(\mathrm{~s}, 3 \mathrm{H}) ;{ }^{13} \mathrm{C}\left\{{ }^{1} \mathrm{H}\right\}\left(101 \mathrm{MHz}, \mathrm{CD}_{3} \mathrm{OD}\right) \delta$ 156.7, $156.6,142.7,142.2,137.0,135.7,134.9,131.6,131.0,130.9,130.8$, $130.6,130.3,130.2,129.4,126.8,95.6,82.3,82.2,73.5,70.70,70.67$, 68.8, 64.1, 63.7, 63.3, 63.2, 62.2, 13.6, 12.03, 11.99; HRMS (ESI) $\mathrm{m} / z$ calcd for $\left[\mathrm{M}+\mathrm{NH}_{4}\right]^{+} \mathrm{C}_{38} \mathrm{H}_{49} \mathrm{BF}_{2} \mathrm{~N}_{3} \mathrm{O}_{10} 756.3480$, found 756.3479 .

General Method for the Ureation Reaction. The appropriate azidomethyl-BODIPY (1 mmol) was added to a mixture of $1 \mathrm{M}$ triethylammonium hydrogen carbonate buffer (TEAB) $(2.6 \mathrm{~mL})$ and 1,4-dioxane $(6 \mathrm{~mL})$ at room temperature. Triphenylphosphine (1.3 equiv) was added, and the reaction was monitored by TLC. After disappearance of the starting material, the solvent was evaporated in vacuo to dryness. The obtained BODIPY dimers were purified by flash chromatography on silica gel.

Compound 15. Azidomethyl-BODIPY 11 (40 mg, $0.05 \mathrm{mmol})$ was reacted with $\mathrm{PPh}_{3}(20 \mathrm{mg}, 0.075 \mathrm{mmol})$ and TEAB $(200 \mu \mathrm{L}, 1 \mathrm{M}$ solution, $0.2 \mathrm{mmol}$ ) following the general procedure ( $\mathrm{rt}$, overnight). The residue was purified by flash silica gel chromatography (7:3 hexane/ethyl acetate) to give derivative $15(31 \mathrm{mg}, 80 \%)$ : red solid; mp 91-92 ${ }^{\circ} \mathrm{C} ;[\alpha]_{\mathrm{D}}{ }^{21}=+563.0\left(\right.$ c $\left.0.02, \mathrm{CHCl}_{3}\right) ;{ }^{1} \mathrm{H}$ NMR $(300$ $\left.\mathrm{MHz}, \mathrm{CDCl}_{3}\right) \delta 7.47(\mathrm{~d}, J=8.0 \mathrm{~Hz}, 2 \mathrm{H}), 7.43(\mathrm{t}, J=7.5 \mathrm{~Hz}, 2 \mathrm{H})$, $7.33(\mathrm{t}, J=7.5 \mathrm{~Hz}, 2 \mathrm{H}), 7.08(\mathrm{~d}, J=7.8 \mathrm{~Hz}, 2 \mathrm{H}), 5.79-5.68(\mathrm{~m}, 8 \mathrm{H})$, $5.33-5.16(\mathrm{~m}, 10 \mathrm{H}), 4.28-3.80(\mathrm{~m}, 16 \mathrm{H}), 2.52(\mathrm{~s}, 6 \mathrm{H}), 2.50(\mathrm{~s}$, $6 \mathrm{H}), 2.07(\mathrm{~s}, 12 \mathrm{H}), 2.02(\mathrm{~s}, 6 \mathrm{H}), 2.00(\mathrm{~s}, 6 \mathrm{H}), 1.31(\mathrm{~s}, 6 \mathrm{H}), 1.26(\mathrm{~s}$, $3 \mathrm{H}) ;{ }^{13} \mathrm{C}\left\{{ }^{1} \mathrm{H}\right\} \mathrm{NMR}\left(126 \mathrm{MHz}, \mathrm{CDCl}_{3}\right) \delta 171.2,171.0,170.4,158.0$, 155.5, 155.4, 141.3, 141.15, 141.11, 137.5, 137.4, 132.9, 132.9, 132.1, $132.0,131.55,131.50,130.48,130.42,129.9,128.7,128.6,128.5$ $128.15,128.10,128.08,128.0,125.12,125.08,75.03,74.97,69.9,69.8$, 65.1, 65.0, 63.4, 63.3, 41.7, 21.1, 20.94, 20.89, 20.76, 13.3, 13.2, 11.71, 11.69; HRMS (ESI) $m / z$ calcd for $[\mathrm{M}+\mathrm{H}]^{+} \mathrm{C}_{81} \mathrm{H}_{91} \mathrm{~B}_{2} \mathrm{~F}_{4} \mathrm{~N}_{6} \mathrm{O}_{21}$ 1581.6378, found 1581.6376; HRMS (ESI) $\mathrm{m} / z$ calcd for $[\mathrm{M}+$ $\left.\mathrm{NH}_{4}\right]^{+} \mathrm{C}_{81} \mathrm{H}_{94} \mathrm{~B}_{2} \mathrm{~F}_{4} \mathrm{~N}_{7} \mathrm{O}_{21}$ 1598.6643, found 1598.6628 .

Compound 16. Azidomethyl-BODIPY $14(26 \mathrm{mg}, 0.04 \mathrm{mmol})$ was reacted with $\mathrm{PPh}_{3}(16 \mathrm{mg}, 0.06 \mathrm{mmol})$ and TEAB $(170 \mu \mathrm{L}, 0.16$ $\mathrm{mmol}$ ) following the general procedure (rt, overnight). The residue was purified by flash silica gel chromatography (9:1 dichloromethane/ methanol) to give derivative $16(19 \mathrm{mg}, 78 \%)$ : red solid; $\mathrm{mp}>300$ ${ }^{\circ} \mathrm{C} ;[\alpha]_{\mathrm{D}}{ }^{21}+664.2\left(c 0.03, \mathrm{CH}_{3} \mathrm{OH}\right) ;{ }^{1} \mathrm{H}$ NMR $\left(400 \mathrm{MHz}, \mathrm{CD}_{3} \mathrm{OD}\right)$ $\delta 7.52-7.41(\mathrm{~m}, 6 \mathrm{H}), 7.17(\mathrm{dd}, J=7.5,1.4 \mathrm{~Hz}, 2 \mathrm{H}), 5.85-5.79(\mathrm{~m}$, $6 \mathrm{H}), 5.70(\mathrm{dt}, J=10.2,1.8 \mathrm{~Hz}, 2 \mathrm{H}), 5.21-5.18(\mathrm{~m}, 4 \mathrm{H}), 4.25(\mathrm{~d}, J=$ 
$16.2 \mathrm{~Hz}, 2 \mathrm{H}), 4.11-4.03(\mathrm{~m}, 6 \mathrm{H}), 3.87-3.70(\mathrm{~m}, 4 \mathrm{H}), 3.68-3.60$ $(\mathrm{m}, 4 \mathrm{H}), 3.49-3.41(\mathrm{~m}, 4 \mathrm{H}), 2.51(\mathrm{~s}, 6 \mathrm{H}), 2.46(\mathrm{~s}, 6 \mathrm{H}), 1.39(\mathrm{~s}, 6 \mathrm{H})$, $1.36(\mathrm{~s}, 6 \mathrm{H}) ;{ }^{13} \mathrm{C}\left\{{ }^{1} \mathrm{H}\right\}$ NMR $\left(101 \mathrm{MHz}, \mathrm{CD}_{3} \mathrm{OD}\right) \delta 159.8,156.9$, $156.4,142.24,142.16,141.6,139.3,134.7,131.6,131.3,130.8,130.74$, $130.70,130.64,130.60,130.5,130.2,129.5,129.4,129.1,82.2,82.1$, 70.8, 70.7, 64.1, 64.0, 63.3, 42.4, 13.7, 11.98, 11.92, 11.89; HRMS (ESI) $m / z$ calcd for $[\mathrm{M}+\mathrm{H}]^{+} \mathrm{C}_{65} \mathrm{H}_{75} \mathrm{~B}_{2} \mathrm{~F}_{4} \mathrm{~N}_{6} \mathrm{O}_{13}$ 1245.5529, found 1245.5552 ; HRMS (ESI) $m / z$ calcd for $[\mathrm{M}+\mathrm{Na}]^{+}$ $\mathrm{C}_{65} \mathrm{H}_{74} \mathrm{~B}_{2} \mathrm{~F}_{4} \mathrm{~N}_{6} \mathrm{NaO}_{13}$ 1267.5348, found 1267.5388.

Photophysical Properties. The photophysical properties were registered in diluted solutions $\left(\sim 2 \times 10^{-6} \mathrm{M}\right)$ and prepared by adding the corresponding solvent (spectroscopic grade, used without furher purification or drying) to the residue from the adequate amount of a concentrated stock solution in acetone, after vacuum evaporation of this solvent. UV-vis absorption and fluorescence (after excitation at $480 \mathrm{~nm}$ ) spectra were recorded on a Varian model CARY 4E spectrophotometer and an Edinburgh Instruments spectrofluorimeter (model FLSP 920), respectively, using quartz cuvettes with an optical path length of $1 \mathrm{~cm}$. Fluorescence quantum yields $(\phi)$ were obtained using PM567 (laser grade from Exciton, $\phi=0.84$ in ethanol) as a reference, from corrected spectra (detector sensibility to the wavelength). The values were corrected by the refractive index of the solvent. Radiative decay curves were registered with the timecorrelated single-photon counting technique as implemented in the aforementioned spectrofluorimeter. Fluorescence emission was monitored at the maximum emission wavelength $(520-525 \mathrm{~nm})$ after excitation (at $500 \mathrm{~nm}$ ) by means of a Fianium pulsed laser (time resolution of picoseconds) with a tunable wavelength. The fluorescence lifetime $(t)$ was obtained after the deconvolution of the instrumental response signal from the recorded decay curves by means of an iterative method. The goodness of the exponential fit was controlled by statistical parameters $\left(\chi^{2}\right.$ and the analysis of the residuals). The radiative $\left(k_{\mathrm{fl}}\right)$ and nonradiative $\left(k_{\mathrm{nr}}\right)$ rate constants were calculated from the fluorescence quantum yield and average lifetime; $k_{\mathrm{fl}}=\phi / \tau$, and $k_{\mathrm{nr}}=(1-\phi) / \tau$.

The photophysical properties at high concentrations in aqueous solutions (Milli- $Q$ water) were recorded using cuvettes with the required optical path length $(l)$ to minimize the re-absorption/reemission phenomena at each concentration $\left(10^{-4} \mathrm{M}-l=0.01 \mathrm{~cm}\right.$, and $\left.2 \times 10^{-5} \mathrm{M}-l=0.1 \mathrm{~cm}\right)$. The fluorescence spectra were recorded in the front-face configuration.

The photoinduced production of singlet oxygen $\left({ }^{1} \mathrm{O}_{2}\right)$ was determined by direct measurement of the luminescence at $1276 \mathrm{~nm}$ with a NIR detector integrated in the aforementioned spectrofluorometer (InGaAs detector, Hamamatsu G8605-23). The ${ }^{1} \mathrm{O}_{2}$ signal was registered in the front configuration (front face), $40^{\circ}$ and $50^{\circ}$ to the excitation and emission beams, respectively, and leaned $30^{\circ}$ to the plane formed by the direction of incidence and registration in cells of $1 \mathrm{~cm}$. The signal was filtered by a low cutoff of $850 \mathrm{~nm}$. The ${ }^{1} \mathrm{O}_{2}$ generation quantum yield $\left(\phi^{\Delta}\right)$ was determined using the equation

$$
\phi^{\Delta}=\phi^{\Delta, \mathrm{r}}\left(\alpha^{\mathrm{r}} / \alpha^{\mathrm{Ps}}\right)\left(\mathrm{Se}^{\mathrm{Ps}} / \mathrm{Se}^{\mathrm{r}}\right)
$$

where $\phi^{\Delta, \mathrm{r}}$ is the quantum yield of ${ }^{1} \mathrm{O}_{2}$ generation for the used reference (in our case, phenalenone). Factor $\alpha=1-10^{-\mathrm{Abs}}$ corrects the different amount of photons absorbed by the sample $\left(\alpha^{\mathrm{Ps}}\right)$ and reference $\left(\alpha^{\mathrm{R}}\right)$. Factor $\mathrm{Se}$ is the intensity of the ${ }^{1} \mathrm{O}_{2}$ phosphorescence signal of the sample $\left(\mathrm{Se}^{\mathrm{Ps}}\right)$ and the reference $\left(\mathrm{Se}^{\mathrm{r}}\right)$ at $1276 \mathrm{~nm}$. Phenalenone in chloroform was used as a reference for visible irradiation $(420 \mathrm{~nm})$, its singlet oxygen quantum yield being $\phi^{\Delta}=$ 0.98. ${ }^{1} \mathrm{O}_{2}$ quantum yields were averaged from five concentrations between $10^{-6}$ and $10^{-5} \mathrm{M}$ in chloroform (spectroscopic grade).

Quantum Mechanic Calculations. Ground state geometries were optimized with the b3lyp hybrid functional, within density functional theory, using the triple valence basis set with one polarization function $\left(6-311 \mathrm{~g}^{*}\right)$. The geometries were considered as energy minima when the corresponding frequency analysis did not give any negative value. All of the calculations were conducted with Gaussian 16.
Lasing Properties. The laser efficiency was evaluated from concentrated solutions (millimolar) of dyes in ethyl acetate contained in $1 \mathrm{~cm}$ optical path length rectangular quartz cells carefully sealed to avoid solvent evaporation during experiments. The liquid solutions were transversely pumped with $5 \mathrm{~mJ}, 8 \mathrm{~ns}$ fwhm pulses from the second $(532 \mathrm{~nm})$ and third $(355 \mathrm{~nm})$ harmonics of a Q-switched Nd:YAG laser (Lotis TII 2134) at a repetition rate of $1 \mathrm{~Hz}$. The exciting pulses were line-focused onto the cell using a combination of positive and negative cylindrical lenses $(f=15$ and $-15 \mathrm{~cm}$, respectively) perpendicularly arranged. The plane parallel oscillation cavity ( $2 \mathrm{~cm}$ length) consisted of a 90\% reflectivity aluminum mirror acting as the back reflector, and the lateral face of the cell acting as the output coupler ( $4 \%$ reflectivity). The pump and output energies were detected by a GenTec power meter. The photostability of the dyes in an ethyl acetate solution was evaluated by using a pumping energy and geometry exactly equal to those of the laser experiments. We used spectroscopic quartz cuvettes with a $0.1 \mathrm{~cm}$ optical length to allow the minimum solution volume $(40 \mu \mathrm{L})$ to be excited. The lateral faces were grounded, whereupon no laser oscillation was obtained. Information about photostabilitiy was obtained by monitoring the decrease in the laser-induced fluorescence (LIF) intensity after 70000 pump pulses and a repetition rate of $10 \mathrm{~Hz}$ to accelerate the experimental running. The fluorescence emission and laser spectra were monitored perpendicular to the exciting beam, collected by an optical fiber, imaged with a spectrometer (Acton Research Corp.), and detected with a charge-coupled device (SpectruMM:GS128B). The fluorescence emission was recorded by feeding the signal into the boxcar (Stanford Research, model 250) to be integrated before being digitized and processed by a computer. The estimated error in the energy and photostability measurements was $10 \%$.

\section{ASSOCIATED CONTENT}

\section{Supporting Information}

The Supporting Information is available free of charge at https://pubs.acs.org/doi/10.1021/acs.joc.1c00413.

Copies of ${ }^{1} \mathrm{H}$ and ${ }^{13} \mathrm{C}$ NMR spectra, photophysical studies for some of the derivatives, and atom coordinates and total energies (in hartrees) in the ground state (b3lyp/6-311G*) for glyco-BODIPYs (13a, 13b, 14, and 16) (PDF)

\section{AUTHOR INFORMATION}

\section{Corresponding Authors}

Ana M. Gómez - Instituto de Química Orgánica General, IQOG-CSIC, 28006 Madrid, Spain; o orcid.org/00000002-8703-3360; Email: ana.gomez@csic.es

J. Cristobal López - Instituto de Química Orgánica General, IQOG-CSIC, 28006 Madrid, Spain; 이이.org/00000003-0370-4727; Email: jc.lopez@csic.es

Jorge Bañuelos - Departamento de Química Física, Universidad del Pais Vasco, UPV-EHU, 48080 Bilbao, Spain; 이이.org/0000-0002-8444-4383; Email: jorge.banuelos@ehu.eus

\section{Authors}

Clara Uriel - Instituto de Química Orgánica General, IQOGCSIC, 28006 Madrid, Spain

Ainhoa Oliden-Sánchez - Departamento de Química Física, Universidad del Pais Vasco, UPV-EHU, 48080 Bilbao, Spain

Inmaculada Garcia-Moreno - Instituto de Química-Física Rocasolano, CSIC, 28006 Madrid, Spain

Complete contact information is available at: https://pubs.acs.org/10.1021/acs.joc.1c00413 


\section{Notes}

The authors declare no competing financial interest.

\section{ACKNOWLEDGMENTS}

The authors gratefully acknowledge the Spanish Ministerio de Ciencia e Innovación for financial support (Projects RTI2018094862-B-100, MAT2017-83856-C3-1-P and -3-P, and PiD2020-114755GB-C31 and -C33) and the Gobierno Vasco (Project IT912-16) for financial support. The authors are indebted to Mr. Diego Pozas and Ms. Marina Rodríguez (IQOG-CSIC) for skillful technical support. A.O.-S. thanks UPV/EHU for her predoctoral fellowship.

\section{DEDICATION}

This article is dedicated to the memory of our mentor (A.M.G., J.C.L.) Prof. Bert Fraser-Reid (1934-2020).

\section{REFERENCES}

(1) (a) Stephens, D. J.; Allan, V. J. Light microscopy techniques for live cell imaging. Science 2003, 300, 82-86. (b) Yuan, L.; Lin, W.; Zheng, K.; He, L.; Huang, W. Far-red to near infrared analyteresponsive fluorescent probes based on organic fluorophore platforms for fluorescence imaging. Chem. Soc. Rev. 2013, 42, 622-661.

(2) (a) Lu, H.; Mack, J.; Yang, Y.; Shen, Z. Structural modification strategies for the rational design of red/NIR region BODIPYs. Chem. Soc. Rev. 2014, 43, 4778-4823. (b) Kowada, T.; Maeda, H.; Kikuchi, $\mathrm{K}$. BODIPY-based probes for the fluorescence imaging of biomolecules in living cells. Chem. Soc. Rev. 2015, 44, 4953-4972.

(3) (a) Loudet, A.; Burgess, K. BODIPY dyes and their derivatives: syntheses and spectroscopic properties. Chem. Rev. 2007, 107, 48914932. (b) Bañuelos, J. BODIPY Dye, the most versatile fluorophore ever? Chem. Rec 2016, 16, 335-348. (c) Kolemen, S.; Akkaya, E. U. Reaction-based BODIPY probes for selective bio-imaging. Coord. Chem. Rev. 2018, 354, 121-134.

(4) (a) Boens, N.; Verbelen, B.; Dehaen, W. Postfunctionalization of the BODIPY core: synthesis and spectroscopy. Eur. J. Org. Chem. 2015, 2015, 6577-6595. (b) Boens, N.; Verbelen, B.; Ortiz, M. J.; Jiao, L.; Dehaen, W. Synthesis of BODIPY dyes through postfunctionalization of the boron dipyrromethene core. Coord. Chem. Rev. 2019, 399, 213024.

(5) (a) Romieu, A.; Massif, C.; Rihn, S.; Ulrich, G.; Ziessel, R.; Renard, P.-Y. The first comparative study of the ability of different hydrophilic groups to water-solubilise fluorescent BODIPY dyes. New J. Chem. 2013, 37, 1016-1027. (b) Kolemen, S.; Akkaya, E. U. Reaction-based BODIPY probes for selective bio-imaging. Coord. Chem. Rev. 2018, 354, 121-134. (c) Agazzi, M. L.; Ballatore, M. B.; Durantini, A. M.; Durantini, E. N.; Tomé, A. C. BODIPYs in antitumoral and antimicrobial photodynamic therapy: an integrating review. J. Photochem. Photobiol., C 2019, 40, 21-48.

(6) Selected references: (a) Franke, J. M.; Raliski, B. K.; Boggess, S. C.; Natesan, D. V.; Koretsky, E. T.; Zhang, P.; Kulkarni, R. U.; Deal, P. E.; Miller, E. W. BODIPY fluorophores for membrane potential imaging. J. Am. Chem. Soc. 2019, 141, 12824-12831. (b) Wang, M.; Zhang, G.; Bobadova-Parvanova, P.; Merriweather, A. N.; Odom, L.; Barbosa, D.; Fronczek, F. R.; Smith, K. M.; Vicente, M. G. H. Synthesis and investigation of linker-free BODIPY-Gly conjugates substituted at boron. Inorg. Chem. 2019, 58, 11614-11621. (c) Kand, D.; Liu, P.; Navarro, M. X.; Fischer, L. J.; Rousso-Noori, L.; Friedmann-Morvinski, D.; Winter, A. H.; Miller, E. W.; Weinstain, R. Water-soluble BODIPY photocages with tunable cellular localization. J. Am. Chem. Soc. 2020, 142, 4970-4974. (d) Yanai, H.; Hoshikawa, S.; Moriiwa, Y.; Shoji, A.; Yanagida, A.; Matsumoto, T. A fluorinated carbanionic substituent for improving water solubility and lipophilicity of fluorescent dyes Angew. Chem., Int. Ed.. 2021, 60, 5168. (7) See also: Blázquez-Moraleja, A.; Álvarez-Fernández, D.; PrietoMontero, R.; García-Moreno, I.; Martínez-Martínez, V.; Bañuelos, J.; Sáenz-de-Santa-María, I.; Chiara, M. D.; Chiara, J. L. A general modular approach for the solubility tagging of BODIPY dyes. Dyes Pigm. 2019, 170, 107545. and references on water-solubilizing approaches cited therein

(8) In a conceptually different approach, BODIPYs have also been used to tag water-soluble compounds. See, for instance: (a) SubirosFunosas, R.; Mendive-Tapia, L.; Sot, J.; Pound, J. D.; Barth, N.; Varela, Y.; Goñi, F. M.; Paterson, M.; Gregory, C. D.; Albericio, F.; Dransfield, I.; Lavilla, R.; Vendrell, M. A Trp-BODIPY cyclic peptide for fluorescence labelling of apoptotic bodies. Chem. Commun. 2017, 53, 945-948. (b) Anai, Y.; Shichijo, K.; Fujitsuka, M.; Hisaeda, Y.; Shimakoshi, H. Synthesis of a $B_{12}$-BODIPY dyad for $B_{12}$-inspired photochemical transformations of a trichloromethylated organic compound. Chem. Commun. 2020, 56, 11945-11948.

(9) (a) Vu, T. T.; Dvorko, M.; Schmidt, E. Y.; Audibert, J.-F.; Retailleau, P.; Trofimov, B. A.; Pansu, R. B.; Clavier, G.; MéalletRenault, R. Understanding the spectroscopic properties and aggregation process of a new emitting boron dipyrromethene (BODIPY). J. Phys. Chem. C 2013, 117, 5373-5385. (b) Doulain, P.-E.; Goze, C.; Bodio, E.; Richard, P.; Decréau, R. A. BODIPY atropisomer interconversion, face discrimination, and superstructure appending. Chem. Commun. 2016, 52, 4474-4477. (c) Descalzo, A. B.; Ashokkumar, P.; Shen, Z.; Rurack, K. On the aggregation behavior and spectroscopic properties of alkylated and annelated borondipyrromethene (BODIPY) dyes in aqueous solution. ChemPhotoChem. 2020, 4, 120-131.

(10) (a) He, X.-P.; Zang, Y.; James, T. D.; Li, J.; Chen, G.-R.; Xie, J. Fluorescent glycoprobes: a sweet addition for improved sensing. Chem. Commun. 2017, 53, 82-90. (b) Thomas, B.; Yan, K.-C.; Hu, X.-L.; Donnier-Maréchal, M.; Chen, G.-R.; He, X.-P.; Vidal, S. Fluorescent glycoconjugates and their applications. Chem. Soc. Rev. 2020, 49, 593-641.

(11) (a) Papalia, T.; Siracusano, G.; Colao, I.; Barattucci, A.; Aversa, M. C.; Serroni, S.; Zappala, G.; Campagna, S.; Sciortino, M. T.; Puntoriero, F.; Bonaccorsi, P. Cell internalization of BODIPY-based fluorescent dyes bearing carbohydrate residues. Dyes Pigm. 2014, 110, 67-71. (b) Martinez-Gonzalez, M. R.; Urías-Benavides, A.; AlvaradoMartínez, E.; Lopez, J. C.; Gomez, A. M.; del Rio, M.; Garcia, I.; Costela, A.; Bañuelos, J.; Arbeloa, T.; Lopez Arbeloa, I.; PeñaCabrera, E. Convenient access to carbohydrate-BODIPY hybrids by two complementary methods involving one-pot assembly of "clickable" BODIPY dyes. Eur. J. Org. Chem. 2014, 2014, 56595663. (c) Zhang, Q.; Cai, Y.; Li, Q.-Y.; Hao, L.-N.; Ma, Z.; Wang, X.J.; Yin, J. Targeted delivery of a mannose-conjugated BODIPY photosensitizer by nanomicelles for photodynamic breast cancer therapy. Chem. - Eur. J. 2017, 23, 14307-14315. (d) Baratucci, A.; Campagna, S.; Papalia, T.; Galleta, M.; Santoro, A.; Puntoriero, F.; Bonaccorsi, P. M. BODIPY on board of sugars: a short enlightened journey up to the cells. ChemPhotoChem 2020, 4, 647-658.

(12) (a) Liu, B.; Novikova, N.; Simpson, M. C.; Timmer, M. S. M.; Stocker, B. L.; Söhnel, T.; Ware, D. C.; Brothers, P. J. Lighting up sugars: fluorescent BODIPY-glucofuranose and - septanose conjugates linked by direct $\mathrm{B}-\mathrm{O}-\mathrm{C}$ bonds. Org. Biomol. Chem. 2016, 14, 5205-5209. (b) Nguyen, A. L.; Griffin, K. E.; Zhou, Z.; Fronczek, F. R.; Smith, K. M.; Vicente, M. G. H. Syntheses of 1,2,3triazole-BODIPYs bearing up to three carbohydrate units. New J. Chem. 2018, 42, 8241-8246.

(13) Selected reviews of CuAAC cycloaddition: (a) Mamidyala, S. K.; Finn, M. G. In situ click chemistry: probing the binding landscapes of biological molecules. Chem. Soc. Rev. 2010, 39, 1252-1261. (b) Agnew, H. D.; Rohde, R. D.; Millward, S. W.; Nag, A.; Yeo, W.-S.; Hein, J. E.; Pitram, S. M.; Tariq, A. A.; Burns, V. M.; Krom, R. J.; Fokin, V. V.; Sharpless, K. B.; Heath, J. R. Iterative in situ click chemistry creates antibody-like protein-capture agents. Angew. Chem., Int. Ed. 2009, 48, 4944-4948.

(14) (a) Boons, G.-J. Strategies in oligosaccharide synthesis. Tetrahedron 1996, 52, 1095-1121. (b) Galonic, D. P.; Gin, D. Y. Chemical glycosylation in the synthesis of glycoconjugate antitumour vaccines. Nature 2007, 446, 1000-1007. (c) Zhu, X.; Schmidt, R. R. New principles for glycoside-bond formation. Angew. Chem., Int. Ed. 
2009, 48, 1900-1934. (d) Demchenko, A. V., Ed. Handbook of Chemical Glycosylation: Advances in Stereoselectivity and Therapeutic Relevance; Wiley-VCH: Weinheim, Germany, 2008.

(15) (a) Shivran, N.; Tyagi, M.; Mula, S.; Gupta, P.; Saha, B.; Patro, B. S.; Chattopadhyay, S. Syntheses and photodynamic activity of some glucose-conjugated BODIPY-dyes. Eur. J. Med. Chem. 2016, 122, 352-365. (b) del Río, M.; Lobo, F.; Lopez, J. C.; Oliden, A.; Bañuelos, J.; Lopez-Arbeloa, I.; Garcia-Moreno, I.; Gomez, A. M. One-pot synthesis of rotationally restricted, conjugatable, BODIPY derivatives from phthalides. J. Org. Chem. 2017, 82, 1240-1247. (c) Kesavan, P. E.; Pandey, V.; Raza, M. K.; Mori, S.; Gupta, I. Water soluble thioglycosylated BODIPYs for mithochondria targeted cytotoxicity. Bioorg. Chem. 2019, 91, 103139. (d) Uriel, C.; Permingeat, C.; Ventura, J.; Avellanal-Zaballa, E.; Bañuelos, J.; Garcia-Moreno, I.; Gomez, A. M.; Lopez, J. C. BODIPYs as chemically stable fluorescent tags for synthetic glycosylation strategies towards fluorescently labeled saccharides. Chem. - Eur. J. 2020, 26, 5388-5399.

(16) Yang, Y.; Yu, B. Recent advances in the chemical synthesis of $C$ glycosides. Chem. Rev. 2017, 117, 12281-12356.

(17) (a) Ferrier, R. J.; Hoberg, J. O. Synthesis and reactions of unsaturated sugars. Adv. Carbohydr. Chem. Biochem. 2003, 58, 55119. (b) Ferrier, R. J.; Zubkov, O. A. Transformations of glycals into 2,3-unsaturated glycosyl derivatives. Org. React. 2003, 62, 569-736. (c) Gomez, A. M.; Lobo, F.; Uriel, C.; Lopez, J. C. Recent developments in the Ferrier rearrangement. Eur. J. Org. Chem. 2013, 2013, 7221-7262. (d) Ansari, A. A.; Lahiri, R.; Vankar, Y. D. The carbon-Ferrier rearrangement: an approach towards the synthesis of C-glycosides. ARKIVOC 2013, 2013, 316-362. (e) Gomez, A. M.; Miranda, S.; Lopez, J. C. Ferrier rearranagement: an update on recent developments. Carbohydr. Chem. 2016, 42, 210-247.

(18) Two very recent manuscripts dealing with the structure of the "Ferrier glycosyl cation" have appeared: (a) Bhuma, N.; Lebedel, L.; Yamashita, H.; Shimizu, Y.; Abada, Z.; Arda, A.; Desire, J.; Michelet, B.; Martin-Mingot, A.; Abou-Hassan, A.; Takumi, M.; Marrot, J.; Jimenez-Barbero, J.; Nagaki, A.; Bleriot, Y.; Thibaudeau, S. Insight into the Ferrier rearrangement by combining flash chemistry and superacids. Angew. Chem., Int. Ed. 2021, 60, 2036-2041. (b) Greis, K.; Kirschbaum, C.; Leichnitz, S.; Gewinner, S.; Schöllkopf, W.; von Helden, G.; Meijer, G.; Seeberger, P. H.; Pagel, K. Direct experimental characterization of the Ferrier glycosyl cation in the gas phase. Org. Lett. 2020, 22, 8916-8919. In the former manuscript, an allyloxycarbenium ion, i.e., a 1,2-unsaturated cation that is resonance-stabilized within the pyranose ring, e.g., 5 (Figure 2), was identified as the intermediate ionic species, whereas in the latter, a cation that is stabilized by the anchimeric assistance of the $\mathrm{C} 4$ neighboring acetyl group was presented. In any event, and pertinent to this work (regardless of the structure of the intermediate), the Ferrier cation is a stabilized, less encumbered, ion than a classical glycosyl cation.

(19) For literature precedents in the $\beta$-glycosylation of pyrrole by glycals, see: Yadav, J. S.; Reddy, B. V. S.; Raman, J. V.; Niranjan, N.; kIRAN Kumar, S.; Kunwar, A. C. InCl $_{3}$-catalyzed stereoselective synthesis of C-glycosyl heteroaromatics. Tetrahedron Lett. 2002, 43, 2095-2098.

(20) The $\beta$-configurational assignment at the anomeric, $\mathrm{C1}^{\prime}$ and $\mathrm{C} 1$ ", carbons was initially based on their ${ }^{1} \mathrm{H}$ NMR coupling constants, which were in agreement with those for unsaturated aryl $\beta$-Cglycosides described by Sinou and co-workers: Brakta, M.; Lhoste, P.; Sinou, D. Palladium (0)-based approach to functionalized $C$ glycopyranosides. J. Org. Chem. 1989, 54, 1890-1896.

(21) The rigorous proof of the $\mathrm{Cl}^{\prime}$ and $\mathrm{Cl}^{\prime \prime}$ configurations on the carbohydrate moieties was subsequently achieved by hydrogenation of compound 13, leading to a BODIPY with grafted saturated pyranoses. In this new derivative (see the Supporting Information for details), the observed coupling constants for the anomeric protons $\left[{ }^{1} \mathrm{H}\right.$ NMR $\left.\left(300 \mathrm{MHz} \mathrm{CDCl}_{3}\right) \delta 4.39\left(\mathrm{dd}, J_{1,2}=11.6,2.5 \mathrm{~Hz}, 2 \mathrm{H}\right)\right]$ were diagnostic for the $\beta$-orientation of the BODIPY substituent at the anomeric position of the carbohydrate.
(22) Lopez, J. C.; del Rio, M.; Oliden, A.; Bañuelos, J.; LopezArbeloa, I.; Garcia-Moreno, I.; Gomez, A. M. Solvent-sensitive emitting urea-bridged bis-BODIPYs: ready access by a one-pot tándem Staudinger/aza-Wittig ureation. Chem. - Eur. J. 2017, 23, 17511-17520.

(23) (a) Roacho, R. I.; Metta-Magaña, A. J.; Peña-Cabrera, E.; Pannell, K. H. Synthesis, structural characterization, and spectroscopic properties of the ortho, meta, and para isomers of $8-\left(\mathrm{CH}_{2}-\mathrm{C}_{6} \mathrm{H}_{4}\right)$ BODIPY and 8-( $\left.\mathrm{MeOC}_{6} \mathrm{H}_{4}\right)$-BODIPY. J. Phys. Org. Chem. 2013, 26, 345-351. (b) Lin, Z.; Kohn, A. W.; Van Voorhis, T. Toward prediction of nonradiative decay pathways in organic compounds II: two internal conversion channels in BODIPYs. J. Phys. Chem. C 2020, 124, 3925-3938.

(24) Oliden-Sánchez, A.; Sola-Llano, R.; Bañuelos, J.; GarciaMoreno, I.; Uriel, C.; Lopez, J. C.; Gomez, A. M. Tuning the photonic behavior of symmetrical bis-BODIPY architectures: the key role of the spacer moiety. Front. Chem. 2019, 7, 801.

(25) Thakare, S.; Stachelek, P.; Mula, S.; More, A. B.; Chattopadhyay, S.; Ray, A. K.; Sekar, R.; Ziessel, A.; Harriman, A. Harriman, Solvent-driven conformational exchange for amide-linked bichromophoric BODIPY derivatives. Chem. - Eur. J. 2016, 22, 14356-14366.

(26) Agazzi, M. L.; Ballatore, M. B.; Durantini, A. M.; Durantini, E. N.; Tomé, A. C. BODIPYs in antitumoral and antimicrobial photodynamic therapy: an integrating review. J. Photochem. Photobiol., C 2019, 40, 21-48. 